\title{
I ndication of Changes in Projecting Organizational Structures under the New Economy
}

\author{
Petra Pártlová1
}

\begin{abstract}
Enterprise Architecture includes organizational and management part and visions and goals of the organization, business processes leading to the goals, innovation processes, control mechanisms, information and communication technologies and others. The paper focuses on one of the most important components of corporate architecture, organizational and management framework of an enterprise in terms of its present state and anticipated changes and the expected development in the context of the emerging new economy. The research was carried out in a sample of 372 enterprises from the whole Czech Republic with the sector (industrial, manufacturing, services and primary sector) and size differentiation (micro-enterprises, small and medium-sized enterprises and large enterprises according to the classification of Ministry of Industry and Trade of the Czech Republic and the EU). The statistical methods were used ( $p$-value with Pearson Chi quadrate output) to analyses the results. The conclusion indicates a possible development in the corporate organization architecture in the context of the paradigm of changes in the external corporate environment.
\end{abstract}

\section{Key words}

Enterprise architecture, organizational and management framework for business, new economy, external business environment.

J EL Classification: L20, L25

\section{Introduction}

With emerging a new economy, seen by Cook (2004), De Cock at al. (2005), Eris and Saatcioglu (2007), Štědron at al. (2009), Kislingerová (2011), and Li and Liu (2011), as the economy with significant changes, especially in the external environment, there is an urgent need of dealing with changes in existing enterprise architecture including the organizational and management framework. The authors (Lansley 1994; Galbraith \& Lawler 1998; Ashkenas at al. 2005; Friesen 2005) believe that the success and performance of enterprises in the future should be based on speed, flexibility, adaptability, agility and integration capability of the enterprises, and on new organizational and managerial relationships and links. Hunter (2002) notices that enterprises need to improve continually. They should innovate their corporate architecture. Then, the task of managers is to determine the direction of development towards adaptable and innovative organizations. Hunter (2002) and Birkinshaw at al. (2002) and Cooper (2004) emphasize the important role of adopting new innovative structures in an organization

1 Ing. Petra Pártlová, Ph.D., The Institute of Technology and Business in České Budějovice, Faculty of Corporate Strategy, De-partment of Management, Okružní 10, 37001 České Budějovice, Czech Republic, partlova@mail.vstecb.cz 
to achieve higher organizational goals. Hunter (2002), Drucker (2007), Johannessen and Skaalsvik (2014) add that organizations should improve continually. They must innovate. Their managers must determine the direction of development towards adaptable and innovative organizations. They found that the current organizational structures need to be changed to achieve higher organizational goals.

As highly vertical and horizontal differentiated organizations are still used in our enterprises, organizational and management barriers, especially in innovative processes, are more and more common as noticed by Ashkenas et al. (2005) and Koster (2014). The rigidity of old structures and their inability to respond flexibly to environmental demands are significant weaknesses in many enterprises. There is consensus that companies respond to new stimuli (e.g. technological and market global changes) by creating new organizational structures (Senge, 1994). On the other hand, other authors warn of these considerations regarding the fundamental re-engineering of the corporate framework. They say that the interference in the development and re-organization of links should not be carried out widely. Ford and Randolph (1992) and Binney and Williams (1995), for example, argue that structural change demands are often just a response to a fashion trend, and that the popularity of "cross-functional organizations" is just one of a many fashion trends. Bridge and Tisdell (2004) and Bryan and Joyce (2005) propose a simpler solution - leaving the advantage of the hierarchical structure and streamlining and simplifying the vertical and linear management, supporting better collaboration and networking. Banner (1995) refers to the costs of the development and implementation of a new organic structure for an enterprise seen as insignificant.

Banner (1995) also notes that the paradigm is not just a shift. People who are satisfied with the bureaucratic structure that corresponds to their paradigmatic beliefs and assumptions will have difficulty in taking over the organic structure. Only large-scale structural changes do not necessarily lead to the transformation of an organization or to its efficiency and performance. Mabey at al. (2001) highlight the efforts of large companies to increase efficiency through the reduction and restructuring of existing organizational structures. However, the changes have not led to any long-term significant increase in efficiency and performance. The organization of the 21st century must find a way to spontaneously shape and reform the executive multidisciplinary teams as a natural way of working. By Miller, this reformation can be achieved (Hesselbein et al., 1997) as follows: the organization adapts to changes in the market environment and the organizational structure fluctuates smoothly to absorb all these changes. Teams will be formed depending on the problem being solved. So, as the problems will be solved gradually, some teams will disappear and others will emerge. The authors perceive the existence of cross-functional and multidisciplinary teams as an advantage to the organization (Katzenbach \& Smith 1993; Senge 1994; Yeatts \& Hyten 1998; Castka at al., 2001). Undoubted advantages are experienced by teams of experts, as they adapt faster and more flexibly to a changing environment (Parker, 1994). These teams are more creative and more focused on customers. Strengthening the powers of these teams also has its disadvantages. Strengthening the powers of self-managed teams can often be counterproductive. An attempt to implement self-managed teams into the organizational structure can result in frustration for both staff and management if they do not adapt to the requirements of self-control (Tata \& Prasad, 2004). Many organizations have restructured their structure to better meet new challenges such as globalization requirements, growing competition, continuous technological innovation, or custom-tailored 
services and products. Beside this, Snow at al. (1996) suggest that the pace of emerging products and technological change will accelerate. New markets will be created. The competitive pressures will arise. This is a challenge for the emergence of new organizational structures that will enable companies to quickly deploy new products and enter new markets, and manage business operations more efficiently.

Network and process structures were created by expanding the matrix structures. They focus on horizontal processes and networking of multifunctional teams. A welldeveloped information network is a prerequisite. The network structure is complex, flat with a large control system focused on creating and maintaining customer relationships (Bartlett \& Goshal, 1997). The basic co-ordination mechanism is team collaboration and customer satisfaction as the main influence on the decision process. Communication takes place in several directions between individual teams, and the managers are owners of individual processes and have sufficient qualifications to enable subordinates to show initiative, to collaborate, and to train (Hunter, 2002). The network structure may not only include teams or functional units within a single organization, but may also involve more enterprises with the same interest. A process-oriented approach comes with new needs, such as the quality of information needed for the decision-making process, or the need to spend more time jointly, so that everyone involved can properly understand who owns the process, and how to enter the decision-making process. On the other hand, this form of organization offers greater scope for promoting local interests of individual groups and for conflicts (Galbraith et al., 2002). By building up versatile multifunctional units within a network organization, not only time savings can be achieved by the management but also it is possible to accelerate the decision-making process itself, including overcoming barriers. Building network structures will allow flexibility and increased adaptability of enterprises (Galbraith at al., 2002; Jones 2012). The interconnection of processes across organizations increases employee involvement and their interest and understanding of the mission and the goal of an enterprise. Current time brings emerging new challenges and opportunities. These responses respond flexibly to those companies who set up independent teams quickly with a strong common interest and focusing on customer requirements and needs. Such teams are called a cell, and the organizational structure linking these cells to the stack is called a "cellular organization." Comparing the teams to a cell, is a best idea seeing the self-operating parts (teams) that respond individually and flexibly to opportunities or unexpected events, always in accordance with the rules and interests of the whole organization. This approach of self-regulation is completely different from the concept of the need for external guidance of individual units (Miles et al., 1997). A critical factor in the cellular management structure is based on its decentralization, the democracies and the autonomy of the parts (Hunter, 2002; Harris \& Raviv, 2002). The decision-making process is implemented on a collaborative basis and guided by customer needs. Creativity and initiative are a basic competitive advantage. Communication takes place between individual cells and the available technologies allow them to set up the form of functioning that best suits the cell. The role of management is to secure the technological, knowledge and thought flow across the organization to enable and motivate individual cells to achieve success (Hunter, 2002).

The authors want discussion about the necessary changes in organizational structures in line with changes taking place in the external environment of enterprises. 


\section{Methodology}

The research was carried in the sample of 456 enterprises from the Czech Republic. A comprehensive questionnaire survey was used. The sample included 109 micro-enterprises, 140 small enterprises, 124 medium-sized enterprises and 83 large enterprises.

The predominance of small and medium-sized enterprises in the sample corresponds to the structure of economic entities in the Czech Republic, characterized by very high share of small and medium-sized enterprises. During testing, the number of enterprises varies depending on the type of query. Data includes information about enterprises that did not answer to questions about enterprise architecture, particularly because of their small organizational framework and a one-step, directive way of managing, these were micro-enterprises in the sector of services. The aim of the paper was to analyze the current state of enterprise architecture from the point of view of the organizational and management framework in the sample of enterprises from the Czech Republic. At the beginning of the research, the slope (the number of management steps in the respective enterprise) and the corporate architecture were assessed from the point of view of sector and size differentiation. The content of the main analytical part was the analysis of the types of organizational and management structures (OMS). Uniform management structure, divisional control structure, combined control structure and other organizational and management structures were tested in terms of frequency of occurrence depending on the size and sectoral nature of the enterprise. The relation between the type of OMS and the profitability of the enterprise was also monitored. The statistical methods were used ( $p$-value with the Pearson Chi test quadrant). Tests were performed at a standard significance level of 0.05 , i.e. $95 \%$ confidence. The end of the paper indicated the expected development of corporate organizational architecture in the context of the paradigm of changes in the external corporate environment.

\section{Results and Discussion}

The first research area was the "slope" of organizational structures, the number of management levels in the enterprise. The analysis of the sample (Table 1) revealed that the slope does not depend on the sector ( $P .=0.1325)$. Such result was not predicted by the author, and it is a significant change from the results of a similarly focused research conducted in the $80^{\prime}$ 's and the $90^{\prime}$ 's of the last century, when such dependence was very significant.

Table 1 Slope of the management structure does not depend on the focus of the enterprise

\begin{tabular}{|l|c|c|c|c|c|}
\hline Number & \multicolumn{4}{|c|}{ Management levels } & \multirow{2}{*}{ Total } \\
\hline Focus & $\mathbf{1}$ & $\mathbf{2}$ & $\mathbf{3}$ & $\mathbf{4 +}$ & \\
\hline primary sector & 5 & 4 & 3 & 2 & 14 \\
\hline services & 97 & 74 & 49 & 29 & 249 \\
\hline manufacturing and industry & 56 & 42 & 64 & 26 & 188 \\
\hline
\end{tabular}




\begin{tabular}{|l|c|c|c|c|c|}
\hline manufacturing and industry, services & 1 & 1 & 2 & & 4 \\
\hline $\begin{array}{l}\text { manufacturing and industry, services, } \\
\text { primary sector }\end{array}$ & & & 1 & & 1 \\
\hline Total & $\mathbf{1 6 2}$ & $\mathbf{1 2 4}$ & $\mathbf{1 2 0}$ & $\mathbf{5 8}$ & $\mathbf{4 5 6}$ \\
\hline
\end{tabular}

Source: author's analysis

In addition to generally valid factors such as the effects of the external environment, increasing competitive pressure, ownership structure, a complementary explanation of this fading says that the number of management levels significantly influences the development of information technology, the qualification structure of employees, especially at management levels. The factor of complexity of applied technologies and links to foreign markets are more important than the focus of the enterprise. The partial analysis of supplementary questions shows that mostly in case of enterprises whose headquarters are outside the territory of our republic there is a lower number of management degrees, it is the opposite for the enterprises owned by domestic entrepreneurs.

The next part of the analysis tested the dependence of the organizational structure on the size of the enterprise and the focus of the company, as shown in Table 2 and 3.

Table 2 Dependence of the organizational and management structure of the enterprise on its size

\begin{tabular}{|l|r|r|l|r|}
\hline \multirow{2}{*}{ Size } & \multicolumn{2}{|l|}{$\begin{array}{l}\text { organizational and management } \\
\text { structure }\end{array}$} & \multirow{2}{*}{ Total } \\
\cline { 2 - 5 } & $\begin{array}{l}\text { Divisional } \\
\text { structure }\end{array}$ & $\begin{array}{l}\text { Combined } \\
\text { structure }\end{array}$ & $\begin{array}{l}\text { Unit } \\
\text { structure }\end{array}$ & \\
\hline small enterprise (less than 50 employees) & 8 & 18 & 102 & 128 \\
\hline micro enterprise (less than 10 employees) & & 8 & 78 & 86 \\
\hline medium enterprise (up to 250 employees) & 13 & 9 & 99 & 121 \\
\hline large enterprise (250+ employees) & 7 & 25 & 46 & 78 \\
\hline Total & $\mathbf{2 8}$ & $\mathbf{6 0}$ & $\mathbf{3 2 5}$ & $\mathbf{4 1 3}$ \\
\hline
\end{tabular}

Source: author's analysis

Note: Enterprises that did not know or did not fall into the divisional combined and unit structure categories (413 enterprises used for the analysis) were filtered.

A dependence of the type of structure on the size was proved (P.value $=1.649 \mathrm{e}$ $06, \mathrm{~V}=0.2999$ ). Unit structure is the most common (micro-enterprises $=90 \%$, small enterprises $=80 \%$, medium-sized enterprises $=65 \%$, large enterprises $=50 \%$ ). Divisional structure is the most common with medium-sized enterprises (23\%) and combined structure is the most common with large enterprises (35\%). A more detailed analysis of the sub-questions revealed, there is a significant terminological illiteracy in some business managers, which is a challenge especially for universities. At the same time, the trend of retreat from traditional business structures was fully confirmed at the expense of the unit structures. This result is further amplified by the fact that this trend 
is the most intense in the largest size groups, which is very important in terms of their future prosperity, but at the same time it is understandable.

Table 3 Dependence of the organizational and management structure of the enterprise on its scope

\begin{tabular}{|l|c|c|c|c|}
\hline \multirow{2}{*}{ Number } & \multicolumn{4}{|c|}{ management structure } \\
\hline Scope & $\begin{array}{l}\text { Divisional } \\
\text { structure }\end{array}$ & $\begin{array}{l}\text { Combined } \\
\text { structure }\end{array}$ & $\begin{array}{l}\text { Unit } \\
\text { structure }\end{array}$ & Total \\
\hline primary sector & & 1 & 9 & 10 \\
\hline services & 20 & 32 & 174 & 226 \\
\hline manufacturing and industry & 7 & 28 & 139 & 175 \\
\hline $\begin{array}{l}\text { manufacturing and industry, } \\
\text { services }\end{array}$ & & 1 & 4 & 4 \\
\hline $\begin{array}{l}\text { manufacturing and industry, } \\
\text { services, primary sector }\end{array}$ & & & 1 & 1 \\
\hline Total & $\mathbf{2 7}$ & $\mathbf{6 2}$ & $\mathbf{3 2 7}$ & $\mathbf{4 1 6}$ \\
\hline
\end{tabular}

Source: author's analysis

Note: Enterprises that did not know or did not fall into the divisional combined and unit structure categories (416 enterprises used for the analysis) were filtered.

A comprehensive analysis significantly proved the predicted development of corporate management structures based on the transformation of classical structures (divisional, combined) into unit management structures. There is a gradual retreat of classical organizational structures such as divisional and combined structures, into the unit structures. Such a trend was subjected to sectoral orientation testing. It was proved that the process of transition to unit organizational structures is not dependent on the sectoral (production) orientation $\mathrm{P} .=0.81$. The factors causing this development will be subjected to further analyses in the research. However, it is assumed that a wide range of factors are involved in this process, mostly from the internal environment of an enterprise. An example of this is the increasingly intensive process of manufacturing specialization, including the field of services, the need for corporate co-operation and the division of labour between different departments, the requirement to increase value added in business processes at all enterprise levels, and the growing importance of specialists in corporate departments. Within the external environment, a significant role is assumed in the change of roles of both suppliers and customers in a market-based business environment, the increasing risk of entry of new competitors and the emergence of substitutes. The question of the specialty of the respective corporate value chain is at the forefront, where the organizational structures of the organization have undoubtedly higher potential value for its appreciation. The author of the paper sees such factor as one of the most important factors of the gradual changes within the enterprise architecture. The writer of the paper also considers the intensity of this process as a very useful point of view, in which both the Czech and foreign literature refers to the gradual transition to the unit structure of an enterprise. However, these structures already represent about 
$80 \%$ of the sample of more than 400 Czech enterprises, which is a very important fact, raising the demand for accelerated theoretical and practical development of this process by the research and academy sphere.

Further analysis aimed at testing the dependence of organizational structures, size and profit of the sample enterprises; see graphs 1, 2, 3 and 4 .

Graph 1 Dependence of the type of the organizational structure and the profit of an enterprise (the whole sample)

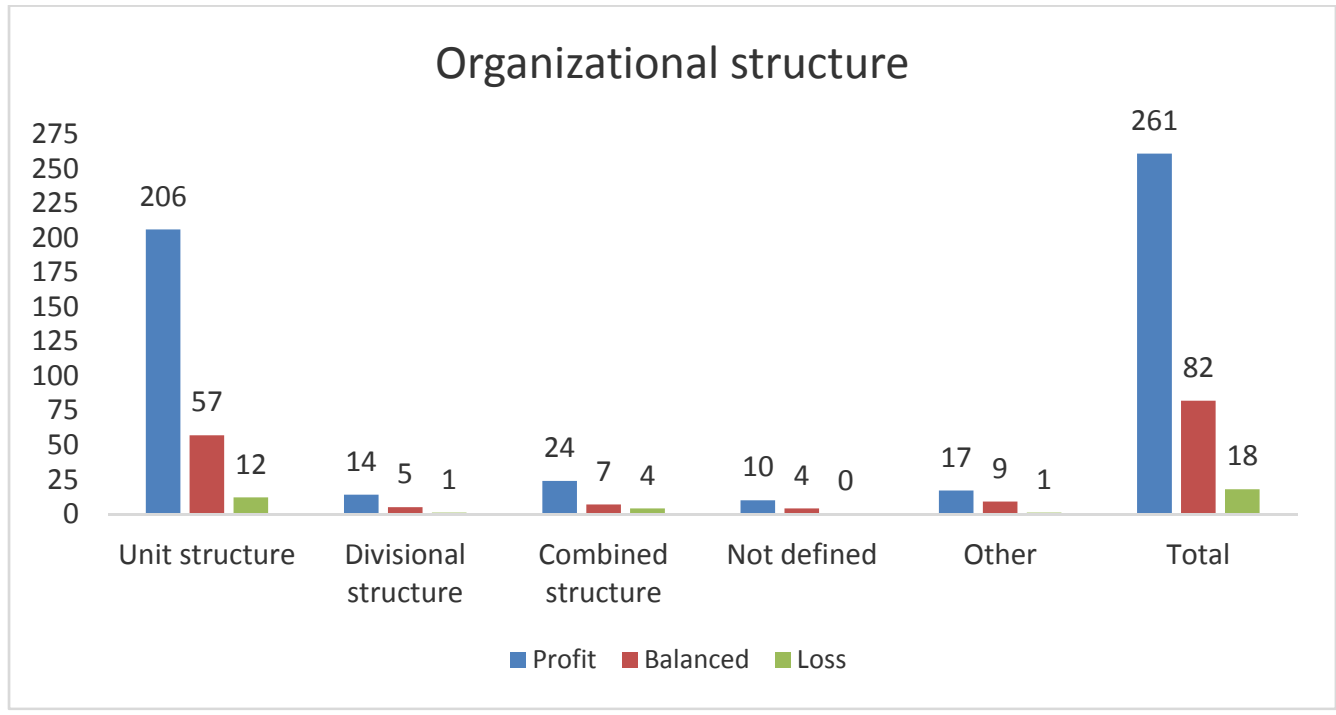

Source: author

Analyzing the whole sample revealed that the frequency and profitability and the balanced profit/loss is most indicated in the unit management structure. Almost $75 \%$ of these enterprises generate profits; $20.7 \%$ is balanced, and $4.4 \%$ report a loss. The second most frequent structure is the combined structure (divisional and unit structure). With this structure, $68.6 \%$ generate profits $20 \%$ of enterprises are balanced, and 11.4 $\%$ generate a loss. The third most common structure is the divisional structure generating profit in $70 \% ; 25 \%$ are balanced and $5 \%$ report a loss. In addition, 14 enterprises did not report the type of its organizational structure. In total, there are $71.4 \%$ of the enterprises reporting profit; $28.6 \%$ are balanced. The loss was not recorded, possibly also due to the overall economic growth in the Czech Republic. In testing 378 SMEs, a p-value was calculated less than the chosen significance level of $5 \%$, therefore we can declare these two variables as X-squared dependent $=182.46, \mathrm{df}=116, \mathrm{p}$-value $=$ $8.071 \mathrm{e}-05 \mathrm{~V}=6.6360$ ). Subsequently, the dependency of enterprises based on the size is analysed. 
Graph 2 Dependence of organizational structure and size category on the profitability of the enterprise in micro-enterprises

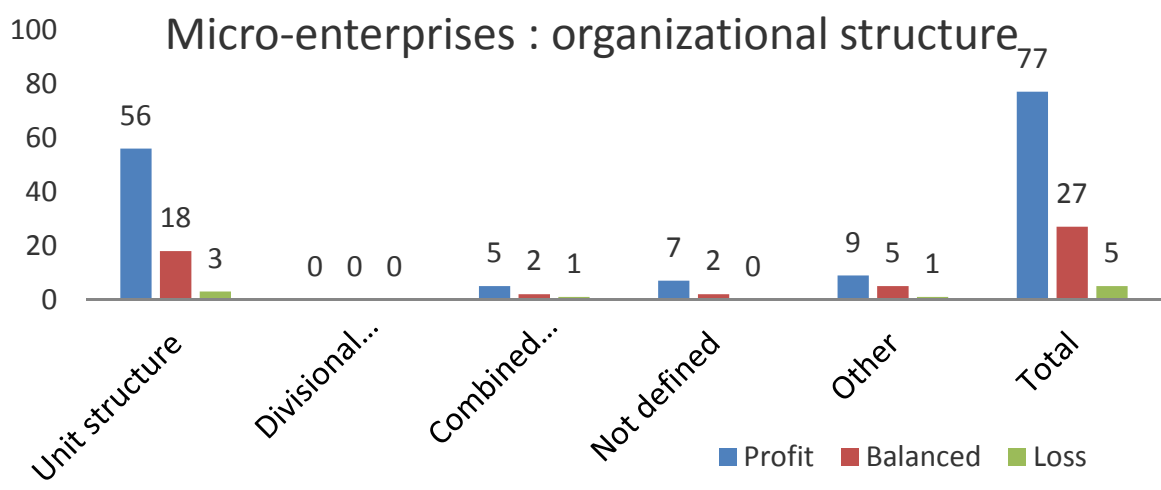

Source: author

In micro-enterprises, $70.6 \%$ use unit management structure. Within these, 72.7 $\%$ generate profit, $23.4 \%$ are balanced and $3.9 \%$ report a loss. Other organizational structures are not represented a lot. It is a very surprising finding, especially with a direct line structure. Micro-enterprises represent a group of 109 enterprises. In the micro enterprise category there are companies with up to 10 employees, often with only one employee - entrepreneurs. When testing micro-enterprises and organizational structure dependence on profitability, the value of $p$-value was calculated to be less than the $5 \%$ significance level, therefore the dependency is confirmed with the micro-enterprises ( $\mathrm{X}$ squared $=89.0591, \mathrm{df}=51, \mathrm{p}$-value $=0.0007739 \mathrm{~V}=5.8837$ ).

Graph 3 Dependence of organizational structure and size category on the profitability of the enterprise in small enterprises

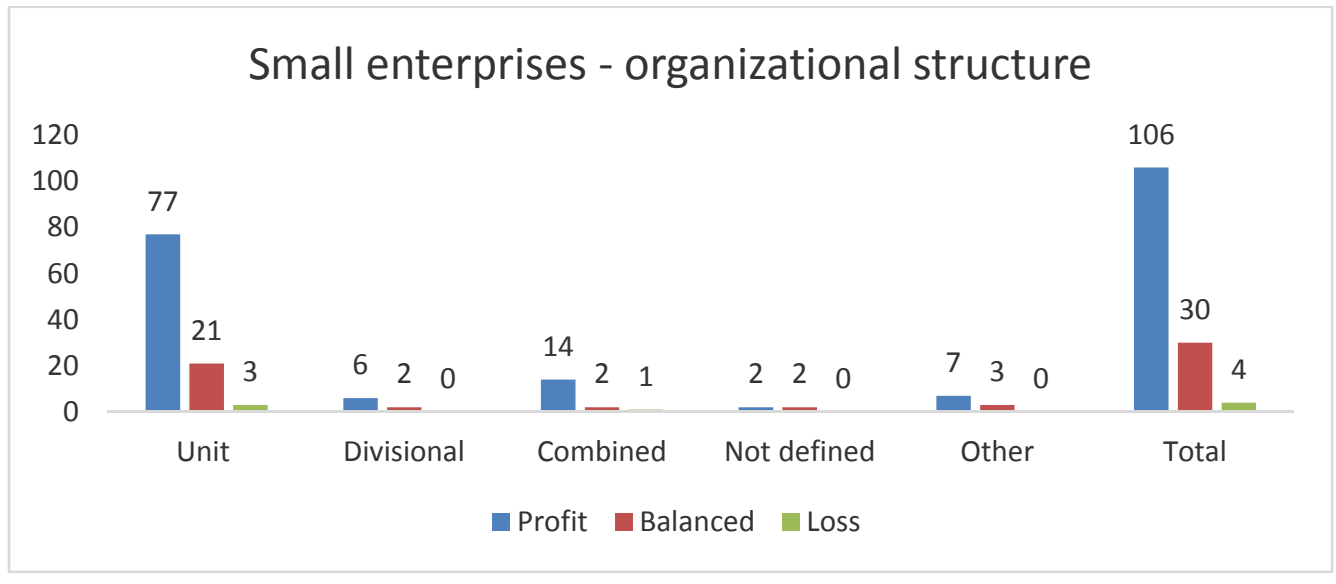

Source: author 
The micro-enterprise, small enterprises mostly use the unit structure (86.4\%). In these enterprises, $63.6 \%$ is profitable, $17.4 \%$ is balanced and $2.5 \%$ is in a loss. Combined structure is the second most common (its frequency is approximately six times less common), with $82.4 \%$ profitable enterprises, 11.8 balanced enterprises and $5.9 \%$ of enterprises in a loss. Four enterprises did not define its structure. Ten enterprises use a different structure. Divisional and other structures are not significant.

There are 140 small enterprises. Analysis of the dependence revealed the following results: $\mathrm{X}$-squared $=912.9716, \mathrm{df}=13, \mathrm{p}$-value $<2.2 \mathrm{e}-16 \mathrm{~V}=54.3667)$. The achieved $p$-value is less than the $5 \%$ significance level chosen by us. There is dependence between the variables.

Graph 4 Dependence of organizational structure and size category on the profitability of the enterprise in middle-sized enterprises

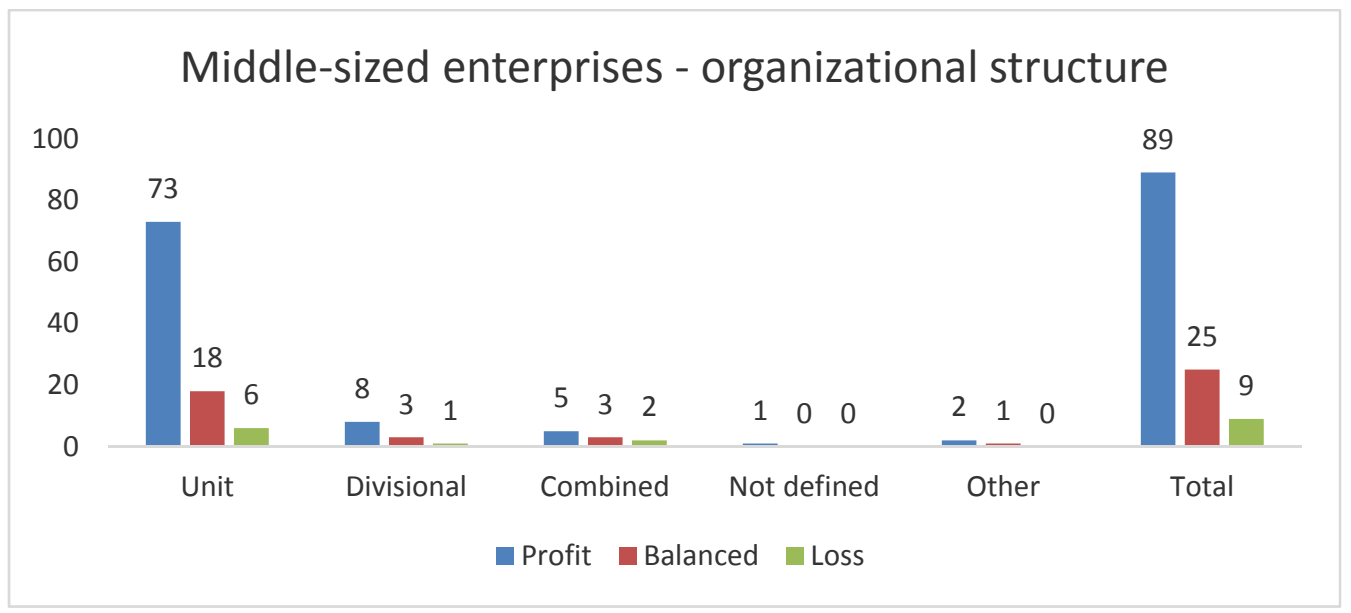

Source: author

Unit structure was also common in middle-sized enterprises (78.9\%). Such enterprises generate profit in $75.3 \% ; 18.6 \%$ are balanced and $6.2 \%$ are in a loss. As expected, divisional control structure is the second most common followed by the combined structure. Regarding the divisional structure, there are $66.7 \%$ of profitable enterprises; $25 \%$ are balanced and $8.3 \%$ in a loss. Regarding the combined structure, there are $50 \%$ of profitable enterprises; $30 \%$ are balanced and $20 \%$ in a loss.

There are 123 middle-sized enterprises in the sample. The following results were found by the dependency test ( $\mathrm{X}$-squared $=505.592, \mathrm{df}=7, \mathrm{p}$-value $<2.2 \mathrm{e}-16 \mathrm{~V}=$ 31.9764). The achieved $p$-value is less than the $5 \%$ significance level, so the variables are dependent. 


\section{Conclusion}

- The analyses of organizational and management structures suggest an intensive process in a slow change of corporate architecture in the Czech Republic.

- The transformation process of corporate organizational structures in the Czech Republic focuses mostly on a shift from traditional structures to unit structures.

- The statistics proved that the process of the shift to unit structures does not depend on different sektors and production types $(P=0.81)$.

- Analysis of sample suggests that the steepness of the organizational structure does not depend on the sector ( $P .=0.1325)$. Such result was not predicted by the researcher. It is a significant change from the results of a similarly focused research conducted in 80-90s of the 20th century, when such dependence was very significant.

-

- Partial analyses of follow-up questions revealed that especially enterprises established outside the Czech Republic have a lower number of management levels compared to the enterprises of Czech owners, and vice versa.

- The analyses indicate the start of the process of gradual reorganization of the enterprise architecture. The degree of their transformation will be increasingly influenced by the specifics of the factors of the internal corporate environment, but the restructuring process will not be of a general nature, they must show a high degree of specificity and originality.

- The number of management levels is significantly limited by the effects of the external environment, increasing the competitive pressure. The ownership structure also affects the number of management levels; in enterprises with headquarters outside the territory of our republic there is a lower number of management levels; compared to the enterprises owned by Czech entrepreneurs.

- The predicted dependence of the type of organizational structure on the size of the enterprise was proved. The most widely used structures include unit and divisional structure; the combined structure is less common. The research confirmed the ongoing process of transformation of classical business structures (divisional, combined) into unit management structures. The dependence of the type of organizational structure on the business sector was not confirmed.

- In the size category of microenterprises is used the unit management structure, where more than $95 \%$ of enterprises generate profit or have a balanced profit/loss. Dependence of the type of organizational structure and profitability was proved.

- Similarly, to micro-enterprises, the small enterprises mostly use unit structure $(90 \%) ; 60 \%$ of which are profitable, $15 \%$ are balanced and $2.5 \%$ are in a loss. Dependence of the type of architecture and profitability was proved, too.

- The medium-sized enterprise category also has the largest representation in the unit management structure, where more than $75 \%$ of businesses generate profit, more than $15 \%$ of businesses are balanced, and the loss is about $6 \%$. In turn, the second structure is the divisional structure followed by the combined structure. Even with this size category of enterprises, the relation between organizational structure and profitability was confirmed. 
Such results are supposed to be discussed in further research. However, they suggest, that it is necessary to re-build the enterprise architecture. Restructuring of organizational structures, however, must not be a mere fashion trend. It must be complex and systemic. In today's turbulent and globalizing surrounding the enterprise need to be flexible to adapt the changes in the market environment. It will be appropriate to transform the organizational structure so that all the planned changes are absorbed by an enterprise.

\section{References}

Ashkenas, R., Ulrich, D., Jick, T. \& Kerr, S. (2005). The Boundaryless organization: breaking the chains of organizational structure. San Francisco: Jossey-Bass.

Banner, D.K. (1995). Designing effective organizations: traditional a transformational view. Thousand Oaks: Sage.

Bartlett, C.A. \& Goshal, S. (1997). The individualized corporation. New York: Harper Business.

Binney, G \& Williams C. (1995). Leaning into the future: changing the way people change organizations. London: Nicholas Brealey Publishing.

Birkinshaw, J., Nobel, R., \& Ridderstråle, J. (2002). Knowledge as a contingency variable: Do the characteristics of knowledge predict organization structure? Organization Science, 13(3), 274-289.

Bridge, A. J., \& Tisdell, C. (2004). The determinants of the vertical boundaries of the construction firm. Construction Management and Economics, 22(8), 807-825.

Lansley, P. (1994). Analysing construction organizations. Construction Management and Economics, 12(4), 337-348.

Bryan, L \& Joyce, C. (2005) The 21st-century organization. McKinsey Quarterly, 3, 2433.

Castka, P, Bamber, C.J., Sharp, J.M., \& Belohoubek, P. (2001). Factors affecting successful implementation of high performance teams. Team Performance Management: An international journal, 7(7/8), 123-134.

Cook, K. S. at al. (2004) Trust and distrust in patient-physician relationships: Perceived determinants of high- and low-trust relationships in managed-care settings In R.M. Kramer \& K.S. Cook (Eds.), Trust and Distrust in Organizations: Dilemmas and Approaches (pp. 65-98). New York: Russell Sage Foundation.

Cooper, D. (2004). Organizational change: From public to private sector-a UK based reflective case study. Journal of American Academy of Business, 5(1/2) 474-481.

De Cock, C., Fitchett, J., \& Volkmann, C. (2005). Constructing the new economy: A discursive perspective. British Journal of Management, 16(1), 37-49.

Drucker, P.F. (2007). Entrepreneurship and Innovation. United States: HarperBusines. Ford, R.C., Randolph, W.A. (1992). Cross-Functional structures: A review and integration of matrix organization and project management. Journal of Management, 18(2), 267-294. 
Johannessen, J. A., \& Skaalsvik, H. (2014). Innovative leadership in organizations: The road to innovation performance. Problems and Perspectives in Management, $12(2), 139-152$.

Friesen, G.B. (2005). Organization design for the 21st Century. Consulting to management, 16(3), 32-51.

Eris, E. D., \& Saatcioglu, O. Y. (2007). Supply chain in the new economy: An approach based on knowledge management. In Proceedings of the European and Mediterranean Conference on Information Systems, EMCIS 2007, 24-26 June 2007 (pp. 521-5214). Valencia, Spain: Polytechnic University of Valencia.

Galbraith, J.R., Downey, D., \& Kates, A. (2002). How networks undergird the lateral capability of an organization - where the works gets done. Journal of Organizational Excellence, 21(2), 67-78.

Galbraith, J.K., \& Lawler, E. (1998). The challenge of change: organizing for competitive advantage. In Mohrman, S.A., Galbraith, J.R. et al. (Eds). Tomorrow's organization: craft winning capabilities in a dynamic world. (pp. 1-20). San Francisco: Jossey- Bass.

Harris, M., \& Raviv, A. (2002). Organization design. Management Science, 48(7), 852865.

Hesselbein, F., at al. (1997). The Drucker Foundation: The Organization of the Future. San Francisco: Jossey-Bass.

Jones, G. R. (2012). Organizational theory, design, and change. London: Pearson.

Hunter, J. (2002). Improving organizational performance by use of effective elements of organizational structure. International Journal of Health Care Quality Assurance, 15(4/5), 12-21.

Katzenbach, J.R., \& Smith, D.K. (1993). The wisdom of teams: creating the high-performance organization. Boston: Harvard Business School.

Koster, F. (2014). "When two worlds collide": Career satisfaction and altruistic organizational citizenship behaviour. International Journal of Business Science and Applied Management, 9(1), 1-12.

Kislingerová, E. at al. (2011). Nová ekonomika. Nové př̌ležitosti? Praha: C.H. Beck.

Mabey, C., Salaman, G., \& Storey, J. (2001). Organizational structuring and restructuring. In Salaman, G. (ed.), Understanding Business organisations. London: Routledge.

Li, H., \& Liu, Z. (2011). Research on organizational structure based on viable system model: How to diagnose the problem of management from the view of knowledge. In Proceedings of the 2011 International Conference on E-Business and E-Government, ICEE2011, 6-8 May (pp.6212-6216), Shanghai, China.

Miles, R. E., Snow, C. C., Mathews, J. A., Miles, G., \& Coleman Jr., H. J. (1997). Organizing in the knowledge age: Anticipating the cellular form. Academy of Management Executive, 11(4), 7-19.

Miller, D. (1997). The future organization: a chameleon in all its glory. In Hesselbein, F., at al. (Eds.), The organization of the future. San Francisco: Jossey-Bass. 
Parker, G.M. (1994). Cross-functional teams: working with allies, enemies, and other. In P. Senge (Eds.), The fifth discipline: the art and practice of the learning organization. New York: Doubleday-Currency.

Snow, C. C., Snell, S., Davison, S.C., Hambrick, D.C. (1996). Use transnational teams to globalize your company. Organizational Dynamics, 24(4), 50-67.

Štědroň, B., Budiš, P., Štědroň, B. jun. (2009). Marketing a nová ekonomika. Praha: C.H. Beck.

Tata, J., \& Prasad, S. (2004). Team self-management, organizational structure, and judgments of team effectiveness. Journal of managerial issues, 16(2), 248-265.

Yeatts, D.E., \& Hyten, C. (1998). High-performing self-managed work teams: a compare son of theory to practice. Thousand Oaks: Sage Publications. 